\title{
Perceived Stress and Coping Strategies among Nursing Students at Ras Al Khaima Medical and Health Science University in the United Arab
}

\section{Emirates}

\author{
Enas Mahrous Abd Elaziz, Lecturer \\ Psychiatric Mental Health Nursing, Faculty of Nursing, Cairo University \\ Amal Gamal Shehata, Assistant Professor \\ Psychiatric Nursing and Mental Health, Faculty of Nursing, Alexandria University
}

\begin{abstract}
Academic stress among college students has been a topic of interest for many years. College students especially freshmen, are particularly prone to stress due to the transitional nature of college life. They may have difficulty in adjusting to more rigorous academic expectations and the need to learn to deal with individuals of different cultural and beliefs. High perceived stress levels and lack of effective coping skills could be a barrier to achieve the challenges of the profession. Objective: assess perceived stress and coping strategies among nursing students at RAK Medical and Health Science University. Setting: The study was conducted in Ras Al Khaima medical and health science universities in nursing college. Subjects: The study subjects comprised 100 undergraduate nursing students at RAKMHSU, United Arab Emirates. Tools: They were socio-demographic profile, Perceived Stress Scale and Adolescent-Coping Orientation for Problem Experiences (ACOPE). Results: The majority of nursing students (91\%) had low to moderate level of stress (49\% and 42\% respectively) and only 9\% had high stress. The students adopted active coping strategies rather than avoidant and seeking professional support coping strategies. No significant difference between PSS level and gender. Conclusion: Nursing students at RAKMHSU had moderate levels of perceived stress; a major source of stress was academic load. The results show strong, negative correlations between perceived stress levels and coping strategies. Recommendations: Psych-educational program, faculty advising system and counseling services are recommended.
\end{abstract}

Keywords: Perceived stress, Nursing college students, Coping strategies.

\section{Introduction}

The prevalence of stresses is increasing among students in recent years $^{(1,2)}$. Stress brings advantages and disadvantages depending on nursing students coping. On one hand, stress can cause students to feel distress or can motivate student for better achievement ${ }^{(3)}$. In addition to stress, Health science college students are subjected to different kinds of stressors, such as the pressure of academics with an obligation to succeed, an uncertain future and difficulties of integrating into the system in addition to clinical experience ${ }^{(4)}$.
Students experience increased tension prior to their clinical rotation and written examination especially their finals. Moreover, clinical sources of stress include those related to clinical competence, fear of failure, interpersonal relations with patients, work overload and concerns about nursing care given to the patient. Other potential sources of stress are excessive assignments, assignment submission deadlines, unclear assignments and relations with faculty members $^{(1)}$. The challenges of nursing studies can be very stressful for students, with busy schedules, critical thinking 
examinations, and clinical experiences at hospitals, students often feel overwhelmed. More specifically, nursing students experience higher levels of stress than other students in similar health related fields ${ }^{(5)}$. Hsieh's (2011) review of multiple studies found that nursing students experience stress from many sources including academic workload, lack of clinical experience, new roles and responsibilities, and poor relationships with clinical staff ${ }^{(6)}$.

Stress is one of the serious issues that affect university student's life. Its effect could be reflected on the students academically and on their mental health, due to the transitional nature of college life ${ }^{(7,8)}$. While studies indicate increased autonomy and independence during the transition period, students experience significant initial difficulty in adjusting to the new environment especially those who migrate for studies $^{(9)}$. Literature review shows that nursing students perceive higher stress because the stress experienced during school could negatively impact patients in the Future; it is well known that nurses who care for themselves are in better positions to adequately care for their patients than nurses who do not ${ }^{(1,2)}$. Therefore, students' ability to recognize oncoming stress, assess the effects of stress on their overall wellbeing, and understand effective coping mechanisms can help them handle stress more effectively ${ }^{(10,11)}$.

Coping with stress for a student nurse is a dynamic and on-going process, aimed at the maintenance of individual integrity, restoration of imbalance and disequilibrium $^{(1)}$. Students will only perceive a situation as stressful if they feel that it threatens their internal or external resources. Depending on how students perceive the situation, they will choose certain coping strategies over others ${ }^{(4)}$. Based on existing literature, nursing students may use emotional- focused coping strategies or problem-focused strategies $^{(12,13)}$. Nursing college is an ideal time for students to become aware of the importance of self-care and its impact on their lives as future health care providers ${ }^{(14)}$. There is a need to review the nursing curriculum and evaluate what impacts students' stress levels, and recognize the effective role of academic advisor to reduce the stress levels of nursing students and enhance students coping strategies. Hence, it is important to assess Perceived Stress and Coping Strategies among Nursing Students at Ras Al Khaima nursing college.

\section{Aim of the Study}

The aim of the study is to identify degree of stress and coping strategies perceived by nursing students at Ras Al Khaima Medical and Health Science University, United Arab Emirates.

\section{Research Questions:}

1. What is the level of stress among nursing students?

2. What are the sources of such stress?

3. Are there any statistically significant differences in the stress level attributed to any variable of socioacademic data?

4. What are the coping strategies used by nursing students at RAKMHSU?

\section{Materials and Method}

\section{Materials}

Design: A descriptive explorative design was used for this study.

Setting: The study was conducted at all nursing departments of the faculty of nursing college at Ras Al Khaima Medical and Health Science University (United Arab Emirates).

Subjects: The study comprised 100 undergraduate nursing students registered in nursing course, academic year 2010-2011 from a total 112 RAKMHSU, United Arab Emirates. 
Tools: To collect data for the present study, the following tools were used:

\section{Tool I: Student's Basic Data Structured Questionnaire}

It was developed by the researcher in order to identify the student's personnel and academic data. The first section, data about the student's socio-demographic characteristics as age, gender, nationality, academic year, residential status and GPA scores (last semester). The Second section was an open-end question related to sources of stress.

\section{Tool II: Perceived Stress Scale (PSS=14)}

It is a 14-items measure designed to determine ones perception of his/ her stressfulness. This scale is used to measure subjectively experienced stress level among college students based on their feelings and thoughts in the last one month (self- report instrument). The total score of the PSS is obtained by reversing the scores of items 4 , $5,6,7,9,10$, and 13 (in the following manner: $0=4,1=3,2=2,3=1$, and $4=0$ ) and subsequently adding the 14 item scores (Cohen, Kamarck\& Mermelstein, 1983) ${ }^{(15)}$. It is five point Likert scale varying from $0=$ never, 1 =almost, $2=$ =sometimes, $3=$ fairly often, to $4=$ very often.

\section{Tool III: Adolescent-Coping Orientation for Problem Experiences (ACOPE)}

The A-COPE is a coping inventory designed to explore adolescent coping behaviours. The A-COPE contains 12 subscales that reflect 12 different coping patterns: ventilating feelings, seeking diversions, developing self-reliance and optimism, developing social support, solving family, avoiding problems, seeking spiritual support, investing in close friends, seeking professional support, engaging in demanding activity, being humorous, and relaxing by the author (Patterson \& McCubbin, 1987) ${ }^{(16)}$. It is a 5 point Likert scale varying from $0=$ never, $1=$ hardily, $2=$ sometimes, $3=$ often, $4=$ most of the time.

\section{Method}

- An official permission for data collection was obtained from the vice dean of nursing college to carry out the study after explaining the aim.

- Tool II and III were translated from English into Arabic; and tested for content validity by a jury of 5 experts in psychiatric and mental health nursing. The Reliability of the tools was tested by the using testretest method.

- A pilot study was conducted on 15 college students randomly from all academic years to ensure the clarity and applicability of the developed tool as well as to estimate the time needed to complete the tools.

- The total study for nursing students/semester was 15 weeks and the students were filling the sheet in the middle of the term (8th week). The students were filling the students stress test before their send up examination in order to address confounding factors for stress other than examination.

- The data collection involved a period of six months starting from the first of December 2010 till the end of May 2011.

\section{Ethical considerations:}

A written consent was obtained from the students after explaining the purpose of the study.

\section{Statistical Analysis}

The statistical analysis was done by using Statistical Package for Social Sciences (SPSS) version 20 was used for analysis. Spearman's correlation was calculated to find relation-ship between PSS and both GPA and coping strategies. 


\section{Results}

Table (1) describes socio-demographic characteristics of the studied nursing students. It was observed that the great majority $(83 \%)$ of nursing students were females, their age ranged between 17 to 20 years, $84 \%$ were resided in the college campus/ hostel, and $63 \%$ non-Arab. As regards academic year, it can be noticed that $38 \%$ were in the 1 st academic year while half of the students between the 2nd and 3rd academic year (22\% and $29 \%$ respectively). Speaking about GPA, two third of students were taking the place from 3.0 to 3.5 GPA (31\% and $34 \%$ respectively), with a Mean \pm SD. $3.04 \pm 0.59$.

Figure (1) The percentages of perceived stress level among nursing students. The majority of nursing students $(91 \%)$ had low to moderate level of stress $(49 \%$ and $42 \%$ respectively) and only $9 \%$ had high stress.

Table (2) Frequency percentages of perceived stress level by nursing students. Nursing students reported that very often perceived stress effectively, successfully and feeling confident about ability to handle personal problems, able to control irritation in life and they were on the top of things and were thinking about the things that to be accomplished $(69 \%, 55 \%, 50 \%$, and $41 \%$ respectively). On the other hand, the students reported that never being upset ,feeling nervous or unable to could not cope with all things that could be do (10\%, 14\%, and $5 \%$ respectively).

Table (3) Frequency percentages of coping strategies used by nursing university students. The most commonly used strategy by the students tried to cope with the stress by Developing social support through Keep up Friendships, Help other People, Apologize to People Say Nice Things to Others $(72.0 \%, 69.0 \%, 68.0 \%$, and $67.0 \%)$, Solving family problems through Go along with parents request, Talk to parents and Talk to brother or sister $(66.0 \%, 63 \%$ and $51 \%$ respectively). Further, it has been seen that most of the time, students reported that stress was relieved to some extent by seeking spiritual support by performing prayers (64\%), seeking diversions by listen to the music, read or watch T.V (59\% and $61 \%$ respectively), divert their mind and relax themselves during the period of stress (57\%). In addition to engaging in demanding activities such as work hard on school work or projects (65\%). In the area of self-reliance, students reported that most of the time tries to think in good things and make their own decisions (62\%). ACOPE showed that around $29 \%$ of the nursing students try to ventilating their feelings by being angry or crying.

It has been further shown that the least common strategies used by nursing students to cope with stress were avoiding coping through smoking or using drugs $(91 \%)$ and seeking professional support or getting professional counseling or help (72\%) and being with the boy/girlfriend (83\%).

Table (4) Comparison between Male and Female nursing students according to Sources of Stresses. It was found a statistical significant difference between male and female nursing students and their sources of stresses regarding exam stress, no of study hours and curriculum/clinical area $\left(\mathrm{P}=0.012 *, \quad 0.007 *\right.$ and $0.020^{*}$ respectively).

Table (5) shows a comparison between male and female nursing students according to their stress level. It was found that $43.4 \%$ of female nursing students comparing with $35.3 \%$ of male students had a moderate perceived stress level, and only $8.4 \%$ of female nursing students had severe perceived stress level. Female students Mean \pm SD was $48.02 \pm 16.74$, while male students Mean \pm SD was $41.39 \pm 22.31$. There is no significant difference between gender and their stress level $\mathrm{t}(\mathrm{p})=1.161(0.259)$.

Table (6) Depicts correlation between perceived stress score levels of nursing students with age. It was observed that students between 19-21 years of age (77\%) were having moderate level of stress while 
$8 \%$ on the same age group had severe degree of stress. There is statistical significant difference between levels of stress and age $\mathrm{P}=0.034^{*}$.

Table (7) illustrates correlation between Perceived Stress score levels of nursing students with their GPA and Coping strategies. As regard to GPA, no statistical significant difference was found with perceived stress ( $\mathrm{r}=-0.014$ and $\mathrm{p}=0.892)$. While a negative significant difference between PSS versus Coping strategies regarding $\mathrm{r}$ and $\mathrm{p}\left(-0.254^{*}, 0.011^{*}\right.$ respectively).

\section{Discussion}

College life is one of the most memorable experiences in an adolescent's life. Researches yet have attached stress to such experience and little research has been conducted on adolescent's college students $^{(6)}$. The aim of this study was to identify degree of stress and coping strategies perceived by nursing students at Ras Al Khaima Medical and Health Science University.

The results indicate that studied university nursing students experienced a moderate stress level (Figure1). Half of the students felt anger, nervousness, and were unable to cope and felt difficulty to overcome stress (Table2). This was consistent with many studies about stress prevalent in nursing students in Health Science Universities ${ }^{(13,17,18)}$. This may be due to the fact that those students faced a transition shock from school to university in addition other stressors, mainly social and academic ones overwhelm college students. Social stressors are the result of the facts that students come from different cities and they try to build new relationships with others. Also, the majority of them live in campus away of their families. While academic stressors may result from the long hours of theoretical and practical parts of nursing courses, in addition to the diversity of clinical experiences. Students face more stressors when they come to college during the first year of their training because of being placed in an unfamiliar environment. This result is in the same line with other studies who revealed that about two thirds of nursing students had moderate stress level ${ }^{(1,13)}$. Another finding goes in line with a longitudinal qualitative study among Swedish nursing schools who had reported moderate stress level by students ${ }^{(19)}$.

The results indicated that $9 \%$ of student's experienced severe levels of stress. This finding is consistent with the findings of previous studies that nursing students experience high levels of stress as a result of academic, interpersonal, intrapersonal, social and financial factors $^{(4,5,29)}$.

Regarding perceived stress level and socio-demographic characteristics. Findings did not reveal statistical significant association between perceived stress level and gender (table 5). This finding however is inconsistent with Tajularipin et al. (2009) who found a statistically significant difference in the reported levels of the various categories of stress among male and female students ${ }^{(20)}$. Moreover, the present study shows no statistical significant difference was found between perceived stresses and GPA (Table7). This finding however is inconsistent with the latest American College Health Association (ACHA, 2014) report indicating that Stress has a negative impact on academic performance $^{(21)}$. On the other side, the present study revealed that students age affect perceived stress (Table 6). This can be explained that students of first and second year had more stress than other following years. The results can contradict those of Hamaideh (2011) stated an increasing rate level of perceived stress among third and fourth year students lead to academic decline ${ }^{(8)}$.

In general, there is a global perception that stress is associated with nursing education. The nursing students were constantly facing demands and challenges leading to stress during their total training 
$\operatorname{program}^{(6)}$. Previous results also proved the main source of stress that affect student's mental health is academic stressors (table4). This is related to exam stress, frequency of examinations, no of study hours, curriculum/clinical area, lack of activities as well as lack of professional guidance and discouraging. This could be explained that problem-based learning (PBL), objective structured clinical exam (OSCE) and self directing learning (SDL) as a new learning strategies in nursing curriculum at RAKMHSU are the major sources of stress than traditional teaching methods as lectures and hand-out, which become necessary in the nursing training as a tool for evaluation/assessment, increase selfconfidence, decision making ability, and to encourage student learning. Some students perceive OSCE as a burden while others consider them helpful for learning. This result is in accordance with other studies carried out by Dyrbe (2009) and Khan et al (2006) indicating higher stress in the female students in Canada and United States where the most important sources of stress for the students were academic pressures, related to nursing training among the first year students in a new problem-based nursing curriculum $^{(22,23)}$. Another finding is in agreement with the present study where the major stressors identified by the students were related to academics ${ }^{(24)}$.

There is great disparity in the type stressors perceived by female and male students in this study, in which female students had more stressors than male nursing students (table 4). This could be explained by the fact that females are more subjected to the community pressure and still under the pressure of the cultural habits. Similarly, these findings are consistent with Kadayam Gomathi and Jayadevan (2013), Abdulghani et al. (2011), and El-Zubeir et al. (2010) who reported that the prevalence of stress is increasing among female students in higher education due to the additional stress of course workload, lack of leisure time, material to be learned, methods of learning, and frequent academic examinations in a competitive environment and group work ${ }^{(17,18,25)}$. In this respect, Melinda (2015) stated that Participation in physical activity classes taken for credit has been found to assist undergraduate students in controlling the stress related to coursework $^{(26)}$.

Coping is an important construct in understanding how adolescents react to the extensive stressors and adjustments they experience $^{(4)}$. In relation to coping, the present study proved that the majority of the students used problem -focused strategies which mean take action to face stress as "seeking social support", "Solving family problems"," "Seeking spiritual support", "Seeking diversion", Relaxing", and "SelfReliance "are the most common and "Seeking professional support" through get professional counselling is the least common coping strategy identified in nursing students (table 3 ). These results may reveal the availability of academic guidance which assists nursing students in understanding the purpose of the curriculum and foster them towards academic success, self-development and lifelong learning. This is in combination with preparing students with courses as communication skills, time and stress management techniques. Furthermore, RAKMHSU is on the process of accreditation through credit hour system which enables students for selfreliance and decides their own subjects through availability of elective courses. This finding is consistent with the findings of a similar study among nursing students at Chiang Mai University which revealed that the most frequently used coping strategies were seeking social support (62.25\%), planful problem solving $(23.73 \%)$ and accepting responsibility $(8.47 \%)^{(28)}$. A study done by Dhar et al. (2009) reported the five most frequently used coping strategies were positive thinking, listening to the music/radio, solving family problems, talk to parents and pray more ${ }^{(29)}$. Also, Singh et al (2011) found that the most commonly used coping strategies transference was used by $77.3 \%$ of the students to relax via 
TV, movies, a shower, and shopping, sleeping and physical exercises ${ }^{(3)}$. On the contrary, the study findings were inconsistent with the findings of the study done on Iranian students which reported being humorous as the least common used strategy $^{(30)}$.

There was a negative significantly perceived stress level was found to be correlated with coping strategies (table 7). This finding incongruent with Hegge (2008) who reported that students who rated their stress during the nursing program as extreme were not statistically different on the use of coping strategies than those who rated stress as moderate to low ${ }^{(31)}$.

There is increase evidence that leads us to believe that nursing students who can at least make the effort to regulate emotions will be less vulnerable to stress inappropriate stress reactions ${ }^{(7)}$. The current study found that students reported that ventilating feelings are the least used coping strategy. "Avoidance", and "seeking professional support ", were also less used coping strategy to the stress experienced (Table 3). This may due to the cultural habits and religion in gulf areas who usually avoid lifestyle of coping.

\section{Conclusion}

Nursing students at RAKMHSU had moderate levels of perceived stress; a major source of stress was academic load. The results show a strong, negative significant relationship between Perceived stress levels and coping strategies.

\section{Recommendations}

Nursing students are on the borderline risk. It is recommended that:
- Psych-educational program that contains stress risk factors, healthy life style, time management strategies, relaxation techniques, and exploration of adaptive and maladaptive way of coping patterns regarding stress situations.

- Faculty advising system should strengthen academic advisor role. Academic advisor should emphasise on the importance of students and faculty handbook during student's orientation. This will give clear goals and university standards from the beginning to overcome student's confusion and unknown. Academic guidance should be enforced within college to follow students, not only for academic issues but social, personal and intrapersonal concerns.

- Counseling services which enhance free counselling services to college students from career counsellors. Promote counselling programs to staff faculty via conferences, seminars and new training course.

- Research: Future researches could also use larger samples, qualitative methodologies or conduct longitudinal studies. Comparative studies among different nursing colleges in UAE.

\section{Limitations of the study:}

Students being of same class and same institution. The sample size also limited and data collection as well as some of the student's decision not to respond to the questionnaire. Therefore, it is difficult to generalize and apply the results of this study to different nursing colleges. 
Table (1): Socio-demographic and academic characteristics of the studied nursing students

\begin{tabular}{|c|c|c|}
\hline Socio-demographic characteristics & $(\mathrm{No}=100)$ & $\%$ \\
\hline \multicolumn{3}{|l|}{ Age } \\
\hline $17-$ & 30 & 30.0 \\
\hline $19-$ & 50 & 50.0 \\
\hline $21-$ & 17 & 17.0 \\
\hline$\geq 23$ & 3 & 3.0 \\
\hline Total & 100 & 100 \\
\hline \multicolumn{3}{|l|}{ Gender } \\
\hline Male & 17 & 17.0 \\
\hline Female & 83 & 83.0 \\
\hline Total & 100 & 100 \\
\hline \multicolumn{3}{|l|}{ Nationality } \\
\hline Arab & 37 & 37.0 \\
\hline Non-Arab & 63 & 63.0 \\
\hline Total & 100 & 100 \\
\hline \multicolumn{3}{|l|}{ Academic } \\
\hline $1^{\text {st }}$ & 38 & 38.0 \\
\hline $2^{\text {nd }}$ & 22 & 22.0 \\
\hline $3^{\mathrm{rd}}$ & 29 & 29.0 \\
\hline $4^{\text {th }}$ & 11 & 11.0 \\
\hline Total & 100 & 100 \\
\hline \multicolumn{3}{|l|}{ Residency } \\
\hline University Hostel & 84 & 84.0 \\
\hline Other & 16 & 16.0 \\
\hline Total & 100 & 100 \\
\hline \multicolumn{3}{|l|}{ GPA } \\
\hline 2.0 & 15 & 15.0 \\
\hline 2.50 & 12 & 12.0 \\
\hline 3.0 & 31 & 31.0 \\
\hline 3.50 & 34 & 34.0 \\
\hline 4.0 & 8 & 8.0 \\
\hline \begin{tabular}{|l|} 
Total \\
\end{tabular} & 100 & 100 \\
\hline $\begin{array}{l}\text { Min. - Max. } \\
\text { Mean } \pm \text { SD. }\end{array}$ & \multicolumn{2}{|c|}{$\begin{array}{c}2.0-4.0 \\
3.04 \pm 0.59\end{array}$} \\
\hline
\end{tabular}




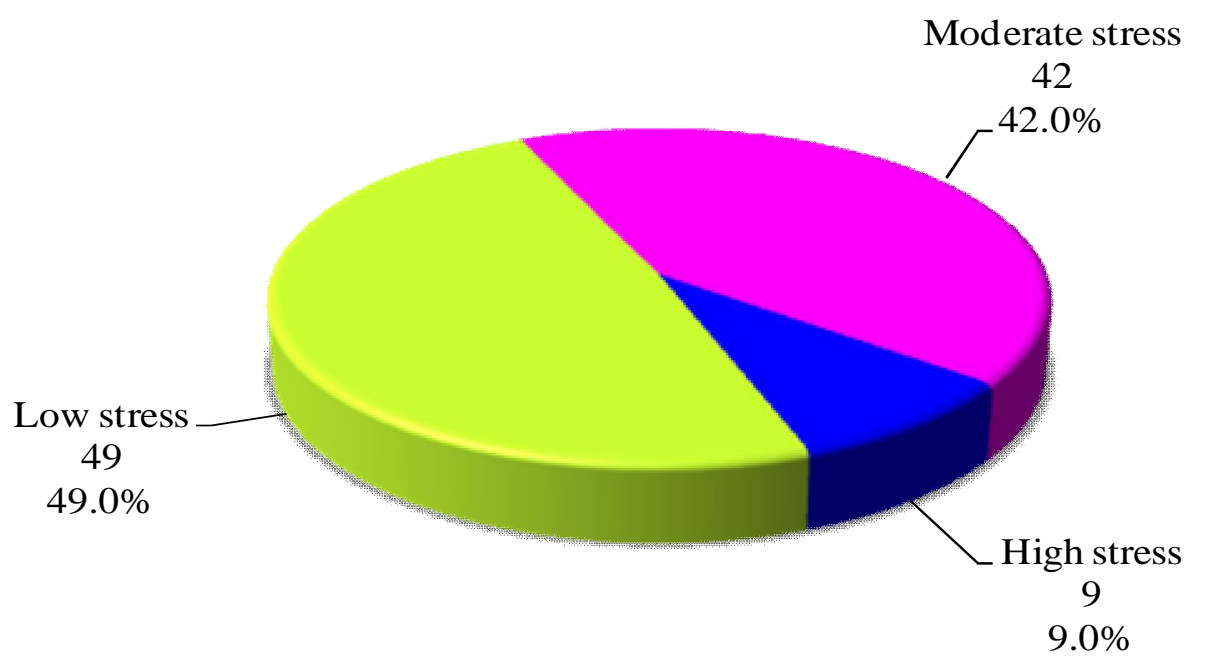

Figure (1): level of Stress among Nursing Students 
Table (2): Frequency percentages of perceived stress level by nursing students $(n=100)$

\begin{tabular}{|c|c|c|c|}
\hline $\begin{array}{l}\text { Items of Perceived Stress scale } \\
\qquad(\mathrm{PSs}=14)\end{array}$ & $\begin{array}{c}\text { Never } \\
\%\end{array}$ & $\begin{array}{c}\text { Sometime } \\
\%\end{array}$ & $\begin{array}{c}\text { Very Often } \\
\%\end{array}$ \\
\hline Being upset that happened unexpectedly & $10(10.0 \%)$ & $55(55.0 \%)$ & $35(35.0 \%)$ \\
\hline $\begin{array}{l}\text { Feeling of unable to control the important things in } \\
\text { life }\end{array}$ & $31(31.0 \%)$ & $47(47.0 \%)$ & $22(22.0 \%)$ \\
\hline Feeling nervous and "stressed" & $14(14.0 \%)$ & $52(52.0 \%)$ & $34(34.0 \%)$ \\
\hline $\begin{array}{l}\text { Able to deal successfully with day to day problems } \\
\text { and annoyances }\end{array}$ & $20(20.0 \%)$ & $55(55.0 \%)$ & $25(25.0 \%)$ \\
\hline $\begin{array}{l}\text { Feeling effectively coping with important changes } \\
\text { that were occurring in life }\end{array}$ & $21(21.0 \%)$ & $55(55.0 \%)$ & $24(24.0 \%)$ \\
\hline $\begin{array}{l}\text { Feeling confident about ability to handle personal } \\
\text { problems }\end{array}$ & $6(6.0 \%)$ & $25(25.0 \%)$ & $69(69.0 \%)$ \\
\hline Feeling that things were going according to own way & $27(27.0 \%)$ & $46(46.0 \%)$ & $27(27.0 \%)$ \\
\hline $\begin{array}{l}\text { Feeling unable to could not cope with all things that } \\
\text { should be do }\end{array}$ & $5(5.0 \%)$ & $50(50.0 \%)$ & $45(45.0 \%)$ \\
\hline Able to control irritation in life & $8(8.0 \%)$ & $37(37.0 \%)$ & $55(55.0 \%)$ \\
\hline Feeling on top of things & $7(7.0 \%)$ & $43(43.0 \%)$ & $50(50.0 \%)$ \\
\hline $\begin{array}{l}\text { Being angered because things were happening outside } \\
\text { of control }\end{array}$ & $20(20.0 \%)$ & $50(50.0 \%)$ & $30(30.0 \%)$ \\
\hline Thinking about the things that to be accomplished & $6(6.0 \%)$ & $53(53.0 \%)$ & $41(41.0 \%)$ \\
\hline Able to control the way of spending time & $22(22.0 \%)$ & $51(51.0 \%)$ & $27(27.0 \%)$ \\
\hline $\begin{array}{l}\text { Feeling that difficulties were piling up so high that } \\
\text { they could not be overcome }\end{array}$ & $19(19.0 \%)$ & $48(48.0 \%)$ & $33(33.0 \%)$ \\
\hline
\end{tabular}


Table (3): Frequency percentage of coping strategies used by nursing university students $(\mathbf{n}=\mathbf{1 0 0})$

\begin{tabular}{|c|c|c|c|}
\hline Coping strategies & $\begin{array}{l}\text { Never } \\
\%\end{array}$ & $\begin{array}{c}\text { Sometime } \\
\%\end{array}$ & $\begin{array}{c}\text { Most of the } \\
\text { time } \\
\%\end{array}$ \\
\hline $\begin{array}{l}\text { Ventilating Feelings } \\
\text { Complain to Friends or Family } \\
\text { Swear Cry Angry / be Sarcastic }\end{array}$ & $\begin{array}{l}21(21.0 \%) \\
29(29.0 \%)\end{array}$ & $\begin{array}{l}42(42.0 \%) \\
42(42.0 \%)\end{array}$ & $\begin{array}{l}37(37.0 \%) \\
29(29.0 \%)\end{array}$ \\
\hline $\begin{array}{l}\text { Seeking Diversions } \\
\text { Read Sleep / Watch T.V / Go To Movie } \\
\text { Listen To Music / Shopping / Play Games }\end{array}$ & $\begin{array}{l}10(10.0 \%) \\
14(14.0 \%)\end{array}$ & $\begin{array}{l}29(29.0 \%) \\
27(27.0 \%)\end{array}$ & $\begin{array}{l}61(61.0 \%) \\
59(59.0 \%)\end{array}$ \\
\hline $\begin{array}{l}\text { Relaxing } \\
\text { Enjoy on hobby / Eat Food / Enjoy Day Dream / Ride } \\
\text { Around in The Car }\end{array}$ & $15(15.0 \%)$ & $28(28.0 \%)$ & $57(57.0 \%)$ \\
\hline $\begin{array}{l}\text { Self-Reliance } \\
\text { Get More Involved in School Activities / Job } \\
\text { Think in Good Things / Make Your Own Decisions } \\
\text { Tell to Yourself That Problem(s) are Not Important }\end{array}$ & \begin{tabular}{|c|}
$10(10.0 \%)$ \\
$9(9.0 \%)$ \\
$30(30.0 \%)$ \\
\end{tabular} & \begin{tabular}{|c|}
$39(39.0 \%)$ \\
$29(29.0 \%)$ \\
$35(35.0)$ \\
\end{tabular} & \begin{tabular}{|c|}
$51(51.0 \%)$ \\
$62(62.0 \%)$ \\
$35(35.0)$ \\
\end{tabular} \\
\hline $\begin{array}{l}\text { Developing social support } \\
\text { Blame Others for What's Going on } \\
\text { Say Nice Things to Others } \\
\text { Apologize to People } \\
\text { Keep up Friendships / Make New Friends } \\
\text { Help Other People Solve Problems }\end{array}$ & \begin{tabular}{|c|}
$65(65.0 \%)$ \\
$7(7.0 \%)$ \\
$9(9.0 \%)$ \\
$9(9.0 \%)$ \\
$6(6.0 \%)$ \\
\end{tabular} & $\begin{array}{l}32(32.0 \%) \\
26(26.0 \%) \\
23(23.0 \%) \\
19(19.0 \%) \\
25(25.0 \%) \\
\end{array}$ & $\begin{array}{c}3(3.0 \%) \\
67(67.0 \%) \\
68(68.0 \%) \\
72(72.0 \%) \\
69(69.0 \%)\end{array}$ \\
\hline $\begin{array}{l}\text { Solving family problems } \\
\text { Talk to your parents } \\
\text { Talk to your brother or sister what bothers you } \\
\text { Go along with parents request } \\
\end{array}$ & \begin{tabular}{|c|}
$15(15.0 \%)$ \\
$21(21.0 \%)$ \\
$9(9.0 \%)$ \\
\end{tabular} & $\begin{array}{l}22(22.0 \%) \\
28(28.0 \%) \\
25(25.0 \%) \\
\end{array}$ & $\begin{array}{l}63(63.0 \%) \\
51(51.0 \%) \\
66(66.0 \%) \\
\end{array}$ \\
\hline $\begin{array}{l}\text { Avoiding } \\
\text { Smoke / Use Drugs } \\
\text { Away From The Home } \\
\text { Try to See Good Things in The Problem } \\
\end{array}$ & $\begin{array}{l}91(91.0 \%) \\
42(42.0 \%) \\
18(18.0 \%) \\
\end{array}$ & \begin{tabular}{|c|}
$4(4.0 \%)$ \\
$25(25.0 \%)$ \\
$34(34.0 \%)$ \\
\end{tabular} & \begin{tabular}{|c|}
$5(5.0 \%)$ \\
$33(33.0 \%)$ \\
$48(48.0 \%)$ \\
\end{tabular} \\
\hline $\begin{array}{l}\text { Seeking spiritual support } \\
\text { Go to church / mosque Pray }\end{array}$ & $12(12.0 \%)$ & $24(24.0 \%)$ & $64(64.0 \%)$ \\
\hline $\begin{array}{l}\text { Investing in close friends } \\
\text { Be close with someone your care about } \\
\text { Be with a boyfriend or girl friend }\end{array}$ & \begin{tabular}{|c|}
$8(8.0 \%)$ \\
$83(83.0 \%)$ \\
\end{tabular} & $\begin{array}{c}27(27.0 \%) \\
5(5.0 \%)\end{array}$ & $\begin{array}{l}65(65.0 \%) \\
12(12.0 \%)\end{array}$ \\
\hline $\begin{array}{l}\text { Seeking professional support } \\
\text { Professional Counseling } \\
\text { Talk to Counselor What Bothers You }\end{array}$ & \begin{tabular}{|l|}
$72(72.0 \%)$ \\
$47(47.0 \%)$ \\
\end{tabular} & $\begin{array}{l}22(22.0 \%) \\
45(45.0 \%) \\
\end{array}$ & $\begin{array}{l}6(6.0 \%) \\
8(8.0 \%)\end{array}$ \\
\hline $\begin{array}{l}\text { Engaging in demanding activities } \\
\text { Do physical activity } \\
\text { Improve Yourself (Get Body in Shape / Better Grades) } \\
\text { Work hard on School Work / Projects }\end{array}$ & \begin{tabular}{|c|}
$25(25.0 \%)$ \\
$16(16.0 \%)$ \\
$9(9.0 \%)$
\end{tabular} & $\begin{array}{l}50(50.0 \%) \\
40(40.0 \%) \\
26(26.0 \%) \\
\end{array}$ & $\begin{array}{l}25(25.0 \%) \\
44(44.0 \%) \\
65(65.0 \%)\end{array}$ \\
\hline $\begin{array}{l}\text { Being Humorous } \\
\text { Joke and Keep a Sense of Humor } \\
\text { Be Funny }\end{array}$ & $\begin{array}{l}5(5.0 \%) \\
2(2.0 \%)\end{array}$ & $\begin{array}{l}42(42.0 \%) \\
39(39.0 \%)\end{array}$ & $\begin{array}{l}53(53.0 \%) \\
59(59.0 \%)\end{array}$ \\
\hline
\end{tabular}


Table (4): Comparison between male and female nursing students according to sources of stresses

\begin{tabular}{||l|c|c|c|c|c||}
\hline \multirow{2}{*}{\multicolumn{1}{|c|}{ Sources of Stresses }} & \multicolumn{2}{|c|}{ Male } & \multicolumn{2}{c||}{ Female } & \multirow{2}{*}{ P } \\
\cline { 2 - 5 } & No. & $\mathbf{\%}$ & No. & \% & \\
\hline Health-related stressors & & & & & \\
Health problems & 4 & 23.5 & 14 & 16.9 & 0.501 \\
Poor physical health & 1 & 5.9 & 11 & 13.3 & 0.685 \\
Academic stressors & $\mathbf{2}$ & $\mathbf{1 1 . 8}$ & $\mathbf{3 9}$ & $\mathbf{4 7 . 0}$ & $\mathbf{0 . 0 0 7 ^ { * }}$ \\
\hline No of study hours & 3 & 17.6 & 18 & 21.7 & 1.000 \\
Faculty/ School & 3 & 17.6 & 5 & 6.0 & 0.133 \\
Discouraging & 4 & 23.5 & 8 & 9.6 & 0.119 \\
Laws & $\mathbf{0}$ & $\mathbf{0 . 0}$ & $\mathbf{2 2}$ & $\mathbf{2 6 . 5}$ & $\mathbf{0 . 0 2 0}$ \\
Curriculum/ clinical & 5 & 29.4 & 22 & 26.5 & 0.772 \\
Lack of professional guidance & 0 & 0.0 & 5 & 6.0 & 0.585 \\
Career change & $\mathbf{1 2}$ & $\mathbf{7 0 . 6}$ & $\mathbf{7 8}$ & $\mathbf{9 4 . 0}$ & $\mathbf{0 . 0 1 2}$ \\
Exam stress & & & & & \\
Psycho-social stressors & 5 & 29.4 & 28 & 33,7 & 0.730 \\
Family /relatives problems & 11 & 64.7 & 42 & 50.6 & 0.424 \\
Lack of activities & 2 & 11.8 & 12 & 14.5 & 1.000 \\
\hline Lack of employment after graduation & & & & \\
\hline \hline
\end{tabular}

$\mathrm{p}: \mathrm{p}$ value for Chi square test

*: Statistically significant at $\mathrm{p} \leq 0.05$ 
Table (5): Comparison between male and female nursing students according to their stress level

\begin{tabular}{|c|c|c|}
\hline $\begin{array}{c}\text { Perceived Stress level } \\
\text { (PSS levels) }\end{array}$ & $\begin{array}{c}\text { Male } \\
(\mathbf{n}=17)\end{array}$ & $\begin{array}{l}\text { Female } \\
(\mathbf{n}=83)\end{array}$ \\
\hline Low $(<50 \%)$ & $9(52.9 \%)$ & $40(48.2 \%)$ \\
\hline Moderate $(50 \%-<75 \%)$ & $6(35.3 \%)$ & $36(43.4 \%)$ \\
\hline Severe $(\geq 75 \%)$ & $2(11.8 \%)$ & $7(8.4 \%)$ \\
\hline$\chi^{2}\left({ }^{\mathrm{MC}} \mathrm{p}\right)$ & \multicolumn{2}{|c|}{$0.458(0.795)$} \\
\hline $\begin{array}{l}\text { Total score } \\
\text { Min. - Max. } \\
\text { Mean } \pm \text { SD. } \\
\text { Median }\end{array}$ & $\begin{array}{c}3.0-22.0 \\
11.59 \pm 6.25 \\
11.0\end{array}$ & $\begin{array}{c}3.0-25.0 \\
13.45 \pm 4.69 \\
14.0\end{array}$ \\
\hline $\begin{array}{l}\text { Mean\% score } \\
\text { Min. - Max. } \\
\text { Mean } \pm \text { SD. } \\
\text { Median }\end{array}$ & $\begin{array}{c}10.71-78.57 \\
41.39 \pm 22.31 \\
39.29\end{array}$ & $\begin{array}{c}10.71-89.29 \\
48.02 \pm 16.74 \\
50.0\end{array}$ \\
\hline $\mathbf{t}(\mathbf{p})$ & \multicolumn{2}{|c|}{$1.161(0.259)$} \\
\hline
\end{tabular}

$\chi 2$ : value for Chi square test MC: Monte Carlo test t: Student t-test

Table (6): Correlation between perceived stress score levels of nursing students with age

\begin{tabular}{|c|c|c|c|c|c|}
\hline \multirow{3}{*}{ Age } & \multicolumn{3}{|c|}{ PSS levels } & \multirow{3}{*}{$\underset{\text { Test }}{\chi^{2}}$} & \multirow{3}{*}{$\begin{array}{c}{ }_{\text {M_Value }} \\
\text { P_V }\end{array}$} \\
\hline & $\begin{array}{c}\text { Low } \\
(<\mathbf{5 0 \%})\end{array}$ & $\begin{array}{c}\text { Moderate } \\
(\mathbf{5 0 \%} \\
<\mathbf{7 5 \%})\end{array}$ & $\begin{array}{l}\text { Severe } \\
(\geq 75 \%)\end{array}$ & & \\
\hline & $(n=49)$ & $(n=42)$ & $(\mathbf{n}=9)$ & & \\
\hline $17-$ & $20(40.8 \%)$ & $10(23.8 \%)$ & $0(0.0 \%)$ & \multirow{4}{*}{13.298} & \multirow{4}{*}{$0.034^{*}$} \\
\hline $19-$ & $19(38.8 \%)$ & $23(54.8 \%)$ & $8(88.9 \%)$ & & \\
\hline $21-$ & $7(14.3 \%)$ & $9(21.4 \%)$ & $1(11.1 \%)$ & & \\
\hline$\geq 23$ & $3(6.1 \%)$ & $0(0.0 \%)$ & $0(0.0 \%)$ & & \\
\hline
\end{tabular}

$\chi 2$ : value for Chi square test MC: Monte Carlo test

Table (7): Correlation between PSS levels of nursing students with their GPA and Coping Strategies

\begin{tabular}{|c|c|c|c|}
\hline \hline \multicolumn{2}{|c|}{ Items } & GPA & Coping score \\
\hline \multirow{2}{*}{ PSS } & $\mathbf{r}$ & -0.014 & $-0.254^{*}$ \\
\cline { 2 - 4 } & $\mathbf{p}$ & 0.892 & $0.011^{*}$ \\
\hline
\end{tabular}

r: Pearson coefficient

*: Statistically significant at $\mathrm{p} \leq 0.05$. 


\section{References}

1. Kadayam G, Gomathi A, Jayadevan S. Causes of Stress and Coping Strategies Adopted by Undergraduate Health Professions Students in a University in the United Arab Emirates. Sultan Qaboos Univ Med J 2013; 13(3):43741.

2. Sanjeev K, Bhukar P. Stress level and coping strategies of college students. Journal of Physical Education and Sports Management 2013; 4(1):5-11.

3. Singh C, Sunita S and Sharma R. Level of stress \& coping strategies used by nursing intern. Nursing \& Midwifery Research Journal 2011; 7 (4) 152-60.

4. Rajesh K. stress and coping strategies among nursing students .Nursing and midwifery Research Journal 2011; 7(4): 141-150.

5. Edward A, Samuel A, Michael M. The Experience of Stress among Nursing Students in Nursing Training Colleges in Tamale, Ghana. International Journal of Psychology and Behavioral Sciences 2015; 5(2): 89-97.

6. Hsieh PL. A school-based health promotion program for stressed nursing students in Taiwan. Journal of Nursing Research (2011); 19(3): 230-236.

7. Ahmed M, Lama M. Assessing stress among university students .American International Journal Of contemporary Research. 2012; 2(2): 110-115.
8. Hamaideh S. Stressors and reaction stressors among university students. International Journal of Social Psychiatry 2011; 57(1): 69-80.

9. Aniket $\mathrm{S}$, Gurvinder $\mathrm{K}$, and Abhijit $\mathrm{P}$ Understanding stress and coping mechanisms in Indian student nurses. SL J Psychiatry 2012; 4 (2): 29-33.

10. Darayus P, Gazder F, Syed H. Stressors, Coursework Stress and Coping Strategies among Medical Students in a Private Medical School of Karachi, Pakistan Education of Medicine Journal 2014 ; 6(3); 20-29.

11. Majumbar B, Ray A. stress and coping strategies among university students: A phenomenological study. Indian Journal Social Science Research 2010; 7(2): 100-111.

12. El-Zubeir MA, Elzubeir KE, Maghzoub ME. Stress and coping strategies among Arab students: towards a research agenda. Educ Health 2010; 23: 355.

13. Shaban A, Khater W, Akhu-Zaheya LM. Undergraduate nursing students stress sources and coping behaviors during their initial period of clinical training: A Jordan perspective. Int J Ment Health Nurs 2014; 23(4): 326-35.

14. Cohen S, Kamarck T, Mermelstein R.. A global measure of perceived stress. Journal of Health and Social Behavior $1983 ; 24,385-396$.

15. Patterson JM, McCubbin HI. Adolescent coping style and behaviors: conceptualizations and measurement. 
Journal of Adolescence 1987; 10, 153 186.

16. Abdulghani HM, Al Kanhal AA, Mahmoud ES, Ponnamperuma GG, Alfaris EA. Stress and its effects on medical students: a cross-sectional study at a college of medicine in Saudi Arabia. J Health Pop Nutr 2011; 29:516-22.

17. El-Gilany AH, Amr M, Hammad S. Perceived stress among male medical students in Egypt and Saudi Arabia: effect of sociodemographic factors. Ann Saudi Med 2008; 28: 442-8.

18. Blomberg K, Bisholt B, Engström, AK, Ohlsson, U, Johansson AS, Gustafsson, M. Swedish nursing students' experience of stress during clinical practice in relation to clinical setting characteristics and the organisation of the clinical education. J Clin Nurs 2014; 23: 2264-2271.

19. Tajularipin S, Aminuddin H, Vizata S. The level of stress among students in urban and rural schools in Malaysia. European Journal of Social Sciences 2009; 10(2): 43-65.

20. American College Health AssociationNational College Health Assessment II: Reference group executive summary spring 2014. Available at: http://www.acha.org. Accessed on: March 6, 2014.

21. Dyrbye LN, Thomas MR, Harper W, Massie FS Jr, Power DV, Eacker A, et al. The learning environment and medical student burnout: a multicentre study. J Med Educ 2009; 43: 274-82.
22. Khan SM, Sajid M, Areef B, Syed AU, Yasir J. Prevalence of depression, anxiety and their associated factors among medical students in Karachi, Pakistan. J Pak Med Assoc 2006; 56: 584-6.

23. Yusoff MS, Rahim AF, Yaacob MJ. Prevalence and sources of stress among Universiti Sains, Malaysia medical students. BMC Med Educ 2007; 7:26.

24. Kadayam G, Gomathi A, Jayadevan S. Causes of Stress and Coping Strategies Adopted by Undergraduate Health Professions Students in a University in the United Arab Emirates. Sultan Qaboos Univ Med J 2013; 13(3): 43741.

25. Melinda J. Differences between undergraduate and graduate students in stress and coping strategies. Journal of Health Promotion 2015; 13(1):13-25.

26. Megumi S, Katsuyuki Y. Stress coping and the adjustment process among university freshman. Counselling Psychology Quarterly 2007; 20 (1): 5167.

27. Chiang CM, Huang ST. Spiritual health, clinical practice stress, depressive tendency and health promoting behaviours among nursing students. Journal of Advanced Nursing 2010; 66(7): 1612-1622.

28. Dhar R., Walia I, Das K. A descriptive study to assess the causes of stress and coping strategies used by the newly admitted basic B.Sc nursing students. 
Nursing Research Journal 2009; 5(1): 31-37.

29. Seyedfatemi N. Experienced stressors and coping strategies among Iranian nursing students BMC Nursing 2016(1). Available http://www.biomedcentral.com/1472$\underline{6955 / 6 / 11 .}$
30. Hegge M. Stressors \& coping strategies of students in accelerated baccalaureate nursing programs. Nurse Educator.2008; 33(1): 26-30.

31. Lennie A. The relationship among young adult college student's depression, anxiety, stress, life satisfaction and coping styles. Issues in Mental Health Nursing 2012; 33(3): 149-156. 